\section{DIGITAL COMMONS \\ @ UNIVERSITY OF SOUTH FLORIDA}

\section{Suburban Sustainability}

\title{
Capital Cost Comparisons between Low Impact Development (LID) and Conventional Stormwater Management Systems in
}

\section{Florida}

\author{
Daniel C. Penniman \\ University of Florida, danielcpenniman@gmail.com \\ Mark Hostetler \\ University of Florida, hostetm@ufl.edu \\ Tatiana Borisova \\ University of Florida, tborisova@ufl.edu \\ Glenn Acomb \\ acomb@ufl.edu
}

Follow this and additional works at: https://digitalcommons.usf.edu/subsust

Part of the Environmental Design Commons, Landscape Architecture Commons, and the Other Economics Commons

\section{Recommended Citation}

Penniman, Daniel C.; Hostetler, Mark; Borisova, Tatiana; and Acomb, Glenn (2013) "Capital Cost Comparisons between Low Impact Development (LID) and Conventional Stormwater Management Systems in Florida," Suburban Sustainability. Vol. 1 : Iss. 2 , Article 1.

http://dx.doi.org/10.5038/2164-0866.1.2.1

Available at: https://digitalcommons.usf.edu/subsust/vol1/iss2/1

This Article is brought to you for free and open access by the Open Access Journals at Digital Commons @ University of South Florida. It has been accepted for inclusion in Suburban Sustainability by an authorized editor of Digital Commons @ University of South Florida. For more information, please contact digitalcommons@usf.edu. 


\section{Capital Cost Comparisons between Low Impact Development (LID) and Conventional Stormwater Management Systems in Florida}

\section{Cover Page Footnote}

Acknowledgements This research was financially supported by the University of Florida's School of Natural Resource and Environment and the Florida Stormwater Association. Important contributions of data and explanations of technical workings were made by David Glunt (Madden Moorehead and Glunt) and Tim Foushee (Ayers Associates). 


\section{Introduction}

Coinciding with the implementation of the 1987 Water Quality Act, regulations began requiring the use of best management practices (BMPs) to control and treat stormwater runoff. Conventional stormwater BMPs rely on "grey" conveyance infrastructure to quickly collect and transport precipitation to be treated in centralized retention facilities (NAHB Research Center Inc 2003). Research to investigate the effectiveness of these "pipe and pond" practices indicates that they have been over-credited for removing constituents associated with stormwater runoff (ERD 2007). Additionally, research has found that the use of conventional stormwater BMPs significantly alters natural flow regimes in a manner that negatively impacts downstream ecosystems (Aquafor Beech 2006). Large centralized stormwater management (SWM) designs also contribute to combined sewer overflows in some places which cause major human health and economic problems (MMSD 2010). Therefore, the use of pipe and pond BMPs is not adequately protecting surface waters from stormwater pollution in many suburban and metropolitan areas.

Low impact development (LID) has been offered as an alternative to the conventional methods of SWM. LID is an ecologically sensitive development strategy that focuses on maintaining a hydrologically functional landscape, postdevelopment. LID has been most widely used in new residential development projects but it has also been used to retrofit in ultra-urban or aging watersheds (USEPA 2000, USEPA 2005). In contrast to conventional SWM, many of its methods are described as decentralized or integrated. LID uses source-control practices which are designed to store and infiltrate precipitation close to where it falls. In addition, biological uptake components are used to assist with cleansing contaminated stormwater (MMSD 2010, Holman-Dodds 2007). The most commonly used LID strategies have been structural BMPs such as pervious surfacing, bioretention cells (also referred to as rain gardens), and vegetated swales (SCDHEC 2012). Research to quantify the environmental benefits of these individual practices demonstrates that they often remove common stormwater pollutants and replicate natural flow patterns better than conventional methods (Hood et al. 2007, Rushton 2001, Ryan 2012, USEPA 2000). Other environmental benefits which have been associated with LID approaches include decreased urban heat island effect, better groundwater recharge, and increased aesthetics and biodiversity (CWP 1998, Montalto et al. 2007).

Despite major surface water issues linked to urbanization and stormwater pollution in Florida, adoption of LID in the state has been slow (Merriam 2011). Nationally, one impediment to using LID has been the concerns that it costs more than conventional SWM practices (Bowman and Thompson 2009, CBP et al. 2002, The Civic Federation 2007, LMI 2005). These perceptions have been 
strongly identified as a barrier to the adoption of LID methods in Florida (Kipp et al. 2011). However, in many documented instances a LID design was able to save money on significant construction costs relative to a pipe and pond design (Kloss and Calarusee 2006, USEPA 2007). Most comparative research of this nature has been done on projects outside of Florida, and local site conditions and soils in Florida may yield different results. The objective of this study is to examine some specific construction costs of a LID SWM design, relative to a conventional design for several Florida projects. The larger intent of this study is to aid professionals in the development sector to better understand certain economic impacts of using LID in several typical Florida site conditions.

\section{Background on Cost Analyses}

The majority of studies tasked with comparing LID's costs to that of pipe and pond methods have solely examined the capital costs of constructing stormwater controls (CRI 2005, EconNorthwest 2007, USEPA 2007). Although this type of comparison lacks a gauge for performance of the alterative development methods, they are important to the general construction industry. This is because most development companies focus on material and implementation costs alone when evaluating the feasibility of the project. Long-term maintenance, or environmental effects of the project have little weight in these cost evaluations, given regulatory requirements are met (Kibert 1999).

Previous research has found that site preparation and infrastructure costs are often lower when using LID as compared to conventional practices (Kloss and Calarusee 2006, USEPA 2007). Coffman (2000) indicates that given favorable conditions, site development costs can be reduced by $25-30 \%$ when using LID because of reduced needs for grading, stormwater piping, curbs, and paving. US EPA (2007), a highly cited study, covered 17 nationally distributed case studies where both a LID and conventional design was completed and compared for the same development project. The LID scheme was the lowest overall-cost option for the majority of projects. Site preparation cost savings ranged from $10 \%$ to $47 \%$ (where reported), and SWM infrastructure savings ranged from $15 \%$ to $72 \%$ (where reported). Areas where construction costs have been noted as being relatively higher for LID projects are landscaping, soil amendments, underdrains and per unit surfacing costs (USEPA 2007, SSI 2009). Also, a decentralized SWM scheme has been pragmatically described as causing the engineering design effort to increase compared to conventional systems (Gordon 2010, Heaney and Sansalone 2012).

Local site conditions and development regulations can have major influences on SWM costs (Sample et al. 2003). As an example, Wossink and Hunt (2003) found that installing bioretention areas in clay soils can cost 16 times more than 
installing the same sized controls in sandy soils. Further, local codes often account for regional conditions such as water table heights and climatic events to develop their flood control measures. Therefore, the pertinence of SWM cost comparisons are largely regional in nature and development professionals need extensive examples from their area of operation to make informed decisions about using alternative practices.

\section{Methods}

\section{Identification of the Study Participants}

The design community, i.e. engineers, landscape architects and environmental consultants, are innovators in the adoption of unconventional development practices (Sherwin 2006). Additionally, design firms are often tasked with devising estimates of probable construction costs for projects. Innovative design firms that work in the area of SWM in Florida were seen as the most prime source of LID vs. conventional cost comparative analyses for proposed projects. Firms that have incorporated LID methods in their Florida projects were identified using a snowball sampling method (Castillo 2009). The implementation of a successful LID project requires a more integrated approach than conventional SWM. Because of this we did not limit our search to civil engineering firms (traditionally responsible for the design of stormwater systems). Many of the firms identified were multidimensional, land-planning groups which employed engineers, architects, and other professional planners.

Thirty-three (33) firms were identified and contacted by phone for an initial interview. This interview was partially scripted regarding willingness to participate in the research, knowledge about LID, availability of cost data on projects, and references for other firms who have utilized LID methods in Florida projects.

\section{Cost Data Questionnaire}

Information about the projects was collected using a formatted spreadsheet questionnaire. The questionnaire was designed based on the cost breakdown reported in US EPA (2007). We sought to identify total project costs and apportioned cost data for planning, site grading (excavation and embankment), stormwater piping, and surfacing. The location, site conditions (major soil type and height of water table) and LID practices used were also requested for each case study. Responses were requested about any notable economic benefits associated with the LID projects such as increased buildable space, permit breaks, grants, and incentives. 
The questionnaire was reviewed and pre-tested by a group of academic and practicing design professionals. It was revised based on the feedback received. A cover letter was used to remind the participants about the phone interview and to provide instructional information. The cover letter was sent by email accompanied by the questionnaire as an attachment. The questionnaire was returned as an email attachment with project data filled in and supporting documentation if applicable.

\section{Data Collected and Results}

Data was received on four projects for which an analysis had been performed to estimate some capital costs of constructing SWM for both a LID and conventional scheme. None of the projects have been constructed using either method. All cost data was received from engineers. Site grading and stormwater piping costs were the most consistently reported and relatively comparable between the alternative SWM schemes. These particular costs typically make up a large portion of total SWM costs, and from one case study collected they made up 30\% of total project costs (less signage, marking, and contingency costs) for the conventional design (see Bradenton case study below). Although inquiries were made about planning, nothing pertaining to these costs was reported for any of the projects. Each LID design used several different practices (Table 1). A summary of each project is given below which primarily focuses on the differentiating features of the LID design.

Table 1

A summary of low impact development practices employed in the 4 Florida case studies

\begin{tabular}{|c|c|c|c|c|}
\hline & $\begin{array}{l}\text { Central FL } \\
\text { Residential }\end{array}$ & $\begin{array}{l}\text { Central FL } \\
\text { Corporate } \\
\text { Center } \\
\end{array}$ & $\begin{array}{l}\text { North Central } \\
\text { FL Residential }\end{array}$ & $\begin{array}{l}\text { Bradenton } \\
\text { Road } \\
\text { Project } \\
\end{array}$ \\
\hline \multicolumn{5}{|l|}{ Structural } \\
\hline Permeable Surfaces & $\mathbf{x}$ & $\mathbf{x}$ & $\mathbf{x}$ & $\mathbf{x}$ \\
\hline Vegetated Swales & $\mathbf{x}$ & $\mathbf{x}$ & $\mathbf{x}$ & $\mathbf{x}$ \\
\hline Bioretention Areas & $\mathbf{x}$ & $\mathbf{x}$ & $\mathbf{x}$ & $\mathbf{x}$ \\
\hline Soil Amendments & & $\mathbf{x}$ & & \\
\hline Rain Barrels/Cisterns & & & $\mathbf{x}$ & \\
\hline Underdrains & $\mathbf{x}$ & & & $\mathbf{x}$ \\
\hline \multicolumn{5}{|l|}{ Non-Structural } \\
\hline Low-impact landscaping $^{\mathrm{a}}$ & $\mathbf{x}$ & $\mathbf{x}$ & $\mathbf{x}$ & \\
\hline $\begin{array}{r}\text { Minimized Soil Stripping } \\
\text { and/or Compaction }\end{array}$ & $\mathbf{x}$ & $\mathbf{x}$ & $\mathbf{x}$ & \\
\hline $\begin{array}{r}\text { Minimized Grading } \\
\text { and/or Filling }\end{array}$ & $\mathbf{x}$ & $\mathbf{x}$ & $\mathbf{x}$ & \\
\hline Narrow Road Design & $\bar{x}$ & $\bar{x}$ & $\bar{x}$ & \\
\hline
\end{tabular}


Data for three projects was from early, base cost analyses performed by engineers. These estimates are used to decide whether or not to move forward and acquire the land in private developments, or to establish fees/bond amounts in municipal projects (D. Glunt, personal communication, Aug. 2011). One project, the Bradenton Roadway Project, was a late cost estimate. Late estimates are calculated over halfway through the design process and most often use adjusted national data or line-item cost data from similar projects in the area. Late estimates, compared to early ones for the same project, represent refined estimates that account for incremental changes to site layout and design.

\section{Central Florida Residential Project, Lake County}

Stage of Design: early

Type: new residential

Size of Project: 170 acres

Major soil type: B, moderate infiltration rates (0.2-6.0 inches per hour)

Average depth of water table on site: 3-6 feet

The residential design had 493 units in both the LID and conventional design. The conventional design utilized three centralized retention basins whereas the LID design incorporated 26 shallow storage areas, most of which were connected by vegetated swales. The LID design maintained much of the hydrological signature and natural capital of the original site. Fifty-one (51) acres of green space was incorporated into the layout of the LID approach. The majority of this green space was designed to serve the dual purpose of community recreation and SWM. The conventional design required 750,000 cubic yards (CY) of grading and 14,000 linear feet (LF) of storm piping. The LID design necessitated 450,000 CYs of grading and 2,000 LF of stormwater piping. Additionally, the diameter size of most stormwater piping in the LID approach was decreased compared to the conventional design. From the estimates, the LID design was projected to save an estimated \$1,000,000 in site grading (a 40\% reduction in site grading costs) and $\$ 1,020,000$ in piping (a $92 \%$ reduction in piping costs).

\section{Central Florida Corporate Center, Seminole County}

Stage of Design: early

Type: new commercial/office

Size of Project: 28 acres

Major Soil Type: C, slow infiltration rates $(<0.06-0.6$ inches per hour)

Average depth of water table on site: 2 feet

The Central Florida Corporate Center design was composed of five retail lots, 14 office lots, and one hotel. In the LID design, all required buffers in between lots 
were used as vegetated swales with the multifunctional purpose of conveyance, infiltration and short-term storage. Park spaces were designed to serve as both community recreation areas and dry detention. Also, a low-lying, naturally vegetated area was incorporated into the plan for attenuation flow, but was designed to be infrequently used. The smart uses of space in the LID design eliminated the need for any on-site retention ponds and helped increase buildable space by approximately $10 \%$ per lot compared to the conventional design. This increased buildable space allowed for an additional one to two lots compared to the conventional design (not considered in cost analysis). Because of the integrated SWM approach, the LID design's site grading and stormwater piping costs combined were projected to be $\$ 1,200,000$ less than the same costs for the conventional design.

\section{North Central Florida Residential, Newberry}

Stage of Design: early

Type: mixed residential/commercial

Size of Project: 250 acres

Major Soil Type: A, high infiltration rates (2-20 inches per hour)

Average depth of water table on site: $10+$ feet

This project was originally designed using conventional pipe and pond techniques which required 34 acres of space for retention ponds throughout the property. The LID re-design utilized "storm trails" to connect large portions of open/green space, and shallow bioretention basins. Storm trails are linear pathways which combine dry detention, and stormwater conveyance. The LID plan maintained 55 acres of green space, 33 acres of which were designed to fill the role of both community recreational space and stormwater infiltration. The LID approach also incorporated existing low-lying areas for depressional storage of pre-treated (through structural LID BMPs) stormwater. The pervious, vegetated spaces in the LID design were expected to manage a large portion of stormwater by infiltration and evapotranspiration. Compared to the conventional design, this practice largely reduced the need to convey stormwater through culverts and it reduced the need to store water in deep excavated retention facilities. The number of development units in the LID and conventional design were the same. Total projected savings from the reduced site grading and piping needs in the LID design was $\$ 2,925,000$.

\section{Roadway Redevelopment Project, Bradenton}

Stage of Design: late

Type: roadway redevelopment

Size of Project: 1.25 miles 
Major soil type: B, moderate to slow infiltration rates (0.2-6.0 inches per hour) Seasonal High Water Table on site: 1-2 feet

The site design was to refurbish and expand an existing roadway. On this site, the stormwater from the section of roadway currently discharges directly into nearby Whitaker Bayou with no treatment or control (a "grandfathered in" drainage system). Due to regional stormwater codes, the proposed roadway improvement triggered regulations which required the treatment of runoff from the site. In 2008, the redevelopment project was designed using pipe and pond practices. Land availability was extremely limited for a conventional system and a major utility relocation was required for the storm sewers and retention pond. In 2010, a LID re-design was used to eliminate the need for the retention pond. This design relied on a pervious sidewalk/bike path and bioswales (incorporated into the median) to infiltrate and store the majority of the site's stormwater.

Line item costs for site grading, stormwater piping, clearing/grubbing, and sidewalk surfacing were reported by the engineer. For an accurate comparison, unit costs for these items had to be standardized due to the fact that the two alternative designs were devised in different years. For a standardization method, we multiplied reported 2008 unit costs by the reported 2008 and 2010 construction units. No pervious concrete was used in the 2008 design but it was estimated to be $\$ 10.50$ more per SY than the 6" sidewalk concrete in the 2010 LID design. To approximate an adjusted SY unit cost for pervious sidewalking we added $\$ 10.50$ to the reported 2008, 6" sidewalk concrete unit cost of $\$ 50$. Similarly, underdrain piping costs were not included in the reported line-item costs for the 2008, conventional design, because they were not utilized in the design. In the 2010 cost estimate, 6" underdrain piping was quoted to be $\$ 17.76$ less per LF than the smallest culvert piping (24") used. Therefore, to estimate an adjusted unit figure for underdrains, we subtracted $\$ 17.76$ from the 2008 unit cost for 24" culvert piping (\$72.56).

The reported unit quantities indicated that when compared to the original design the LID design reduced excavation by 7,015 CYs, decreasing this particular capital cost by $\$ 44,405$. Alternatively, the LID design needed 7,345 CYs more embankment, (mostly to form the vegetated swales) which increased this cost by $\$ 80,795$ (table 2) compared to the pipe and pond design. Therefore, total grading costs were $\$ 36,390$ more for the LID design than for the conventional one. As far as stormwater piping, the conventional design required 9,084 LF of culvert piping, whereas the LID design required 1,367 LF. The conventional design needed a larger range of shapes and sizes of piping than did the LID design. Culvert piping was largely reduced in the LID design because the concentration on source control eliminated the need for water to be conveyed large distances. Although culvert piping was reduced, 10,000 LF of underdrain 
piping was required (estimated to cost $\$ 548,900$ ) in the LID design that was not needed in the conventional design. Combining just the site grading and piping costs for both designs and then comparing these total costs resulted in the LID design being $\$ 237,850$ cheaper.

Because this case study had more detailed numbers, we could continue our analyses further. The amount of clearing and grubbing projected to be needed for the LID design was 4.83 acres less (saving $\$ 93,301$ ) than for the conventional design. Surfacing costs were relatively more in the LID design because pervious concrete was used and because 285 SY more sidewalk area was needed for subsurface retention. Overall the LID design's surfacing costs were $\$ 132,102$ (table 2) more than the pipe and pond design.

The additional embanking, sidewalk surfacing, and underdrain piping was necessary to increase infiltration capacity which ultimately led to reduced excavation and culvert piping required. Combining solely the line-item costs reported here; clearing and grubbing, site grading, piping, and sidewalk surfacing, the LID design was $\$ 199,049$ less than the conventional design.

Table 2

Selected capital costs compared for the Bradenton Road Project Case Study

\begin{tabular}{|c|c|c|c|c|}
\hline Item & Conventional & LID & $\begin{array}{c}\text { LID } \\
\text { Savings }\end{array}$ & \% Savings \\
\hline Excavation costs (@ \$6.33/CY) & $\$ 107,705$ & $\$ 63,300$ & $\$ 44,405$ & $41 \%$ \\
\hline Embankment (@ \$11.00/CY) & $\$ 29,205$ & $\$ 110,00$ & $-\$ 80,795^{\mathrm{a}}$ & $-277 \%$ \\
\hline $\begin{array}{l}\text { Piping costs (@ variable costs depending } \\
\left.\text { on size of pipe }{ }^{b}\right)\end{array}$ & $\$ 923,375$ & $\$ 649,135$ & $\$ 274,240$ & $30 \%$ \\
\hline $\begin{array}{l}\text { Clearing and grubbing costs (@ } \\
\$ 19,317 / \mathrm{AC})\end{array}$ & $\$ 220,793$ & $\$ 127,492$ & $\$ 93,301$ & $42 \%$ \\
\hline $\begin{array}{l}\text { Sidewalk Surfacing (@ } \$ 43 / 4 ” S Y, \$ 50 / \\
6 " \text { SY, and } \$ 60.5^{c} / \text { pervious concrete SY) }\end{array}$ & $\$ 419,454$ & $\$ 551,556$ & $-\$ 132,102^{a}$ & $-31 \%$ \\
\hline Total & $\$ 1,700,532$ & $\$ 1,501,483$ & $\$ 199,049$ & $12 \%$ \\
\hline $\begin{array}{ll}\text { a. } & \text { Negative numbers indicate that L } \\
\text { b. } & \text { Includes underdrain piping for pe } \\
\text { c. } & \text { This unit cost estimate is explain }\end{array}$ & $\begin{array}{l}\text { st more } \\
\text { Is surfacing } \\
\text { ove in the case }\end{array}$ & description & & \\
\hline
\end{tabular}

\section{Discussion}

The reported cost comparative figures were for two large residential projects, one mixed residential/commercial project, and an urban roadway redevelopment project. For the four Florida case studies, a LID approach consistently saved money on excavation (total grading costs were more in the Bradenton roadway project) and stormwater piping. Surfacing and embankment costs were observed to be notably greater for the LID design in one detailed case study. Below we discuss these specific costs.

Total grading costs were lower for the majority of LID designs because deep 
and expansive retention facilities (that must be dug out and cleared for) could be diminished. The reduction in centralized storage was achieved by incorporating several primary LID principles. These included the preservation of vegetated/pervious spaces, the focus on infiltration based practices and the integration of stormwater storage into multi-functional spaces. The Bradenton road project was the one project where overall grading costs were relatively more with the LID scheme. This was because embankment costs were considerably higher for the LID design in order to form vegetated swales on this site. However, savings from reduced excavation, piping and clearing/grubbing made up for the increased costs in embankment and surfacing. Thus, even if certain costs increase due to the use of LID it may help to reduce overall costs. This is especially true in projects where site conditions make incorporating centralized retention areas especially challenging and expensive, or in areas where the site conditions are well-suited for LID practices.

A reduction in stormwater conveyance costs was also repeatedly found to be associated with the LID design of projects. Managing stormwater in decentralized/integrated areas (such as small bioretention areas incorporated into medians or pervious parking areas) minimizes the need for infrastructure to transport stormwater long distances. Although conveyance is still necessary in most LID designs, vegetated swales are often used which are drastically less expensive per unit than hard conveyance infrastructure. The distributed, sourcecontrol tactics of the Central Florida Residential Project's LID design reduced stormwater piping costs by $92 \%$. William and Wise (2009) similarly found that a LID design reduced the need for conveyance infrastructure and this was a significant factor in reducing costs.

The comparison for the Bradenton Road project illustrates a typical tradeoff that must be evaluated when considering the use of pervious surfaces as a primary SWM tool. Pervious surfaces are well documented as costing \$1-10 more per square foot than conventional, non-porous, concrete surfacing (LIDC 2002). But, when pervious surfaces are designed correctly as a SWM system with underdrains and suitable underlying storage capacity, they can reduce the amount of pond space necessary (CRI 2005). Although these integrated and flexible SWM approaches of LID may be more complicated to design for, they have shown to help increase buildable space, as identified in the corporate center case study (Kent 2011). These types of tradeoffs must be given adequate consideration and be fully evaluated to understand whether a LID approach is cost competitive.

It is acknowledged that the findings only consider a portion of total capital costs that ultimately must be evaluated by development professionals. For example, design costs were completely void from the obtained data. This is an area in great need for future research attention. However, the identified savings on significant line-item costs suggests that LID could be a cost effective approach. 
These findings can help professionals in the development sector make more confident decisions about utilizing LID practices, possibly increasing its implementation in Florida and elsewhere.

\section{References}

Aquafor Beech Ltd. 2006. Stormwater Management and Water-course Impacts: The Need for a Water Balance Approach. Project No. 64651. http://sustainabletechnologies.ca/wp/wp-content/uploads/2013/01/ABLWater-Bal-Report_NOV-28-06-FINAL.pdf

Bowman, T. and Thompson, J. 2009. "Barriers to Implementation of Low-Impact and Conservation Subdivision Design: Developer Perceptions and Resident Demand." Landscape and Urban Plann. 92 (2): 96-105. Accessed December $12,2012$.

Castillo, J. J. 2009. Snowball Sampling. Accessed online from ExperimentResources at http://www.experiment-resources.com/snowball-sampling.html.

Center for Watershed Protection (CWP). 1998. Better Site Design: A Handbook for Changing Development Rules in Your Community. Ellicott City, MD.

Cheasapeake Bay Program (CBP) et al. 2002. Proceedings of Three Workshops on Impediments to Low Impact Development and Environmental Sensitive Design. STAC Pub. 02-003.

The Civic Federation. 2007. Managing Urban Stormwater with Green Infrastructure: Case Studies of Five U.S. Local Governments. Chicago, IL. http://www.cnt.org/repository/GreenInfrastructureReportCivicFederation\%20 10-07.pdf.

Coffman, L.S. 2000. "Low-impact development design: a new paradigm for stormwater management mimicking and restoring the natural hydrologic regime, an alternative stormwater management technology." Presented at the Natl. Conference on Tools for Urban Water Resource Managment and Protection, Cincinnati, OH 158-167.

Conservation Research Institute (CRI). 2005. Changing Cost Perceptions: Analysis of Conservation Development. http://www.chicagowilderness.org/ files/1613/3087/0421/Cost_Analysis_Exec_Summary.pdf.

ECONorthwest. 2007. The Economics of Low-Impact Development: A Literature Review, by E. MacMullen and S. Reich, Eugene, OR.

Environmental Research and Design (ERD), Inc. 2007. Evaluation of Current Stormwater Criteria within the State of Florida. by H. H. Harper and D.M. Baker. Orlando, FL

Gordon, E. 2010. "Implementing LID for New Development." Stormwater 11(5). Accessed December 29, 2011.

Heaney, J.P., and Sansalone J. 2012. A Vision for Urban Stormwater 
Management in 2050. In Toward a Sustainable Water Future-Visions for 2050. Virginia: ASCE Press.

Holman-Dobbs, J.K. 2007. "Towards Greener Stormwater Management." J. of Green Build. 2(1) 68-96. Accessed October 12, 2012. http://www.journalof greenbuilding.com/doi/abs/10.3992/jgb.2.1.68.

Hood, M. J., et al., 2007. "Comparison of Stormwater Lag Times for Low Impact and Traditional Residential Development." J. of Am. Water Resour. Assoc. 43(4) 1036-1046.

Kent, A. 2011. "Commercial Development Meets New Hydromodification and LID Requirements." CE News. http://www.cenews.com/print-magazine article-commercial_development_meets_n-8206.html

Kibert, C. J. 1999. Reshaping the Built Environment: Ecology, Ethics, and Economics. Washington DC: Island Press.

Kipp, J.M. et al. 2011. "Implementing Low-Impact Development in Florida: Practitioners' Perspectives." Fla. Watershed J. 4(1) 12-18. http://www. bluetoad.com/publication/?i=60407\&pre $=1$.

Kloss, C., and Calarusee, C. 2006. Rooftops to Rivers: Green Strategies for Controlling Stormwater and Combined Sewer Overflows. New York: Natural Resour. Defense Council. http://www.nrdc.org/water/pollution/rooftops /contents.asp.

LMI Government Consulting. 2005. Low-Impact Development Strategies and Tools for Local Governments: Building a Business Case. By L.M. Powell et al. LID50T1 McLean, VA.

Low Impact Development Center (LIDC). 2002. "Urban Design Tools: Low Impact Development." Permeable Pavers, Cost. http://www.lidstormwater.net/permpaver_costs.htm. Last Accessed Oct. 2010.

Merriam, J. 2011. "Low-Impact Development Comes to Florida." Fla Watershed J. 4(1), 1-6. http://www.bluetoad.com/publication/?i=60407\&pre=1.

Milwaukee Metropolitan Sewage District (MMSD). 2010. Fresh Coast Green Solutions: Weaving Milwaukee's Green \& Grey Infrastructure for a Sustainable Future. Milwaukee, WI. http://v3.mmsd.com/AssetsClient/ Documents/sustainability/SustainBookletweb1209.pdf.

Mohamed, R. 2006. "The Psychology of Residential Developers: Lessons from Behavioral Economics and Additional Explanations for Satisficing." J. of Plann. Educ. and Research 26, 28-37.

Montalto, F., et al. 2007. "Rapid Assessment of the Cost-Effectiveness of Low Impact Development for CSO Control." Landscape and Urban Plann. 82(3), 1-15.

National Association of Home Builders (NAHB). Research Center Inc. 2003. The Practice of Low Impact Development. Upper Marlboro, MD.

Rushton, B.T. 2001. "Low-Impact Parking Lot Design Reduces Runoff and 
Pollutant Loads." J. of Water Resour. Plann. and Mgmt. http://ascelibrary.org /doi/abs/10.1061/ 40430\%281999\%29120.

Ryan, J., et al. 2012. "LID success Stories in Florida." Fla. Watershed J. (5)3, 47. http://bluetoad.com/publication/?i=111103

Sample, D. J., et al. 2003. "Costs of Best Management Practices and Associated Land for Urban Stormwater Control." J. of Water Resour. Plann. and Mgmt. 129 (1): 59-68.

Sherwin, D. 2006. "Reducing the Cost of Green." J. of Green Build. Feb., 1 (1): 46-54. http://dx.doi.org/10.3992/jgb.1.1.46

South Carolina Dept. of Health and Environmental Control (SCDHEC). Bureau of Water. 2012. "Protect the Environment through Stormwater Management." Accessed February 10, 2013. https://www.scdhec.gov/ environment/ water/ swater/LIDs.htm\#top

The Sustainable Sites Initiative (SSI). 2009. The Case for Sustainable Landscapes. http://www.sustainablesites.org/report/ The\%20Case $\% 20$ for $\%$ 20Sustainable \%20Landscapes_2009.pdf

United States Environmental Protection Agency (USEPA). Office of Water. 2000. Low Impact Development, a Literature Review." EPA-841-B-00-005, Washington, DC.

USEPA. 2005. "Low-Impact Development Pays Off." Nonpoint Source NewsNotes, 75, 7-10. http://www.epa.gov/NewsNotes/issue75/75issue.pdf.

USEPA. Nonpoint Source Control Branch. 2007. Reducing Stormwater Costs through LID Strategies and Practices. EPA-841-F-07-006 Washington, DC. http://water.epa.gov/polwaste/green/costs07_index.cfm.

Williams, S., and Wise, W.R. 2009. "Economic Impacts of Alternative Approaches to Storm-Water Management and Land Development." J. of Water Resour. Plann. and Mgmt. http://dx.doi.org/10.1061/(ASCE)07339496(2009)135:6(537).

Wossink, A., and Hunt, B. 2003. "The Economics of Structural BMPs in North Carolina." WRRI344. http://www.bae.ncsu.edu/stormwater/ PublicationFiles/ EconStructuralBMPs2003.pdf 